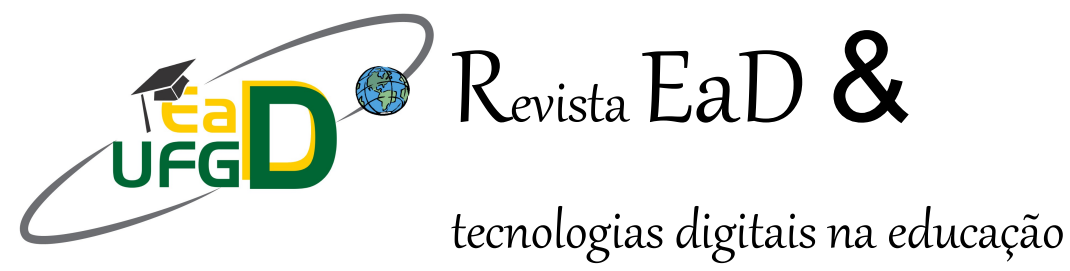

\title{
Relato de Experiência: a literatura visual no aprendizado dos surdos
}

\author{
Anay Matos Rodrigues de Souza ${ }^{13}$, UFGD \\ Rutnéia de Ávila Pereira ${ }^{14}$, UFGD \\ Juliana Maria da Silva Lima ${ }^{15}$, UFGD
}

\begin{abstract}
Resumo: $O$ presente trabalho tem como objetivo apresentar uma peça teatral sobre Leonardo da Vinci elaborado por acadêmicas do curso de licenciatura em Letras Libras da Faculdade de Educação a Distância - EaD da Universidade Federal da Grande Dourados (UFGD) com o objetivo na Literatura Visual, mostrando a cultura surda e entrelaçando com a história da Educação dos surdos em certo recorte diacrônico da Língua de Sinais, destacando as contribuições do Programa Institucional de Bolsas de Iniciação à Docência (PIBID) na formação acadêmica. O subprojeto Letras Libras é desenvolvido em uma escola da rede pública estadual, no município de Dourados, Mato Grosso do Sul.
\end{abstract}

Palavras-chave: Letras/Libras, PIBID, Leonardo da Vinci, Literatura Visual.

\section{Introdução}

O presente relato apresenta vivências proporcionadas através do Programa Institucional de Bolsas de Iniciação à Docência - PIBID, subprojeto Letras-Libras, no desenvolvimento do projeto do primeiro semestre de 2016.

A peça teatral apresentada contou com a participação de oito bolsista de iniciação à docência e duas supervisoras integrantes do PIBID-Letras Libras/EaD/UFGD. O tema trabalhado era sobre a história de Leonardo da Vinci e a educação de surdos da época. A escolha do tema foi de acordo com proposta a ser trabalhado no primeiro semestre de 2016 nas Salas de Recurso Multifuncional (SRM) das escolas estaduais do município de Dourados/MS.

\footnotetext{
${ }^{13}$ Acadêmica de Letras Libras, bolsista do subprojeto de Letras Libras do PIBID/EaD/UFGD.

${ }^{14}$ Acadêmica de Letras Libras, bolsista do subprojeto de Letras Libras do PIBID/EaD/UFGD.

${ }^{15}$ Doutoranda em Educação pela FAED/UFGD, Professora do Letras Libras, Coordenadora do subprojeto Letras Libras do PIBID/EaD/UFGD.
} 
Oprojeto foi baseado na cultura e na literatura surda, conforme pesquisas e estudos realizados a cultura surda é fortemente voltada para o visual. Para isso utilizamos alguns elementos da literatura visual, como: caracterização das personagens (roupas, cabelos e acessórios), cenário, a peça foi toda desenvolvida em língua de sinais.

Para Strobel (2008) a cultura surda é o jeito surdo de entender através de suas percepções visuais é capaz de modificar ajustando de maneira que acrescente para a construção de sua própria identidade cultural.

Segundo Porto e Peixoto (2011) os processos de apropriação dos saberes por meio da literatura visual surgem no instante em que as pessoas surdas são apresentadas às "produções imagéticas de sua língua". Sendo assim, o veio receptor principal para a pessoa surda é a visão, e tal apropriação se dá a todo o momento, por meio de diálogos estabelecidos em língua de sinais, pela observação de cenários e situações e dentre os variados processos de comunicação. Na literatura surda, a arte se estabelece por meio de livros virtuais, da escrita de sinais, teatro, poemas visuais, entre outros.

A história de Leonardo da Vinci foi narrada, a partir da articulação entre sua característica como inventor com a história da educação dos surdos daquela época. Onde o enredo foi conduzido pelo próprio Leonardo da Vinci, que contou um pouco da sua história e suas invenções, por exemplo: as máquinas voadoras, engrenagem, bicicleta, paraquedas, obras e pinturas. Em seguida, a personificação da Mona Lisa, obra que teve diversas releituras, relatou como foi pintada em torno dos anos de 1503 a 1506, na cidade de Florença na Itália.

Na trama surge uma moça que se passando por vizinha de Leonardo da Vinci explicando como era a interação de Leonardo da Vinci com as pessoas.

Ao interligar a história de Leonardo da Vinci com a história da educação de surdos, surgem na trama novos personagens daquela época.

O primeiro é Gerolamo Cardano apresentando como era a educação dos surdos explicando os registros das suas experiências como médico que em suas investigações com bases na fisiologia e anatomia humana sobre o aproveitamento da condutibilidade óssea do som, conclui que a escrita poderia representar os sons da fala ou representar as ideias de pensamentos, assim a surdez não prejudicava a aprendizagem, uma vez que os surdos poderiam aprender a escrever e assim expressar seus pensamentos e tinham a habilidade de raciocinar.

De acordo com Reis (1992), Fornari afirma que "Cardano foi o primeiro a afirmar que o surdo deveria ser educado e instruído, afirmando que era crime não instruir um surdo - mudo".

O personagem de Pedro Ponce de Leon relata que no Monastério, onde havia voto de silêncio, as pessoas se comunicavam com gestos. A partir dessa constatação, 0 monge teve a ideia de utilizar essa estratégia com os surdos e posteriormente, desenvolveu o alfabeto manual. Pedro Ponce de Leon foi considerado o pioneiro na educação de surdos, seus alunos eram crianças surdas, filhos de aristocratas ricos que tinham recursos. Seu trabalho com crianças surdas focalizou em ensinar a escrever, ensinava utilizando a escrita, gestos simples e o alfabeto manual que permitia ao estudante que aprendesse a soletrar toda a palavra.

A educação dos surdos foi retratada através do personagem Juan Pablo Bonet, que apresentou a maneira ensinada para os surdos: a ler, falar e a proibição do uso da língua de sinais, destacando-se o uso do método oral. 
Na história da educação dos surdos a língua de sinais foi banida a partir do congresso de Milão de 1880, e dessa forma, foi imposto o oralismo para todo sujeito surdo.

Segundo Perlin e Strobel (2008) esse modelo de "concepção de educação" está para um modelo clínico com objetivo de "integrar" o sujeito surdo na comunidade de ouvintes e para que a total integração seja completa o surdo deve oralizar bem para preencher o requisito exigido pela sociedade de "normalidade".

Segundo Strobel (2009) essas consequências pesaram muito na qualidade da educação dos surdos, as crianças surdas ficaram com as "habilidades sociais limitadas" e com uma "qualificação inferior". Começando assim uma longa jornada na luta da comunidade surda para reconhecer seu "direito linguístico cultural" e evitar a extinção da língua de sinais.

Rijo (2009) durante sua pesquisa de campo relata a opinião de uma intérprete que acredita que:

Em primeiro lugar é importante que o professor conheça a cultura surda, como a língua brasileira de sinais - Libras, para que possa comunicar-se com alunos surdos. O professor deve aceitar que existem diferenças dentro da escola. Se estas duas características forem compreendidas, o professor será capaz de preparar aulas onde alunos diferentes poderão aprender. (RIJO, 2009, p.26)

Com o projeto percebe-se a importância de mostrar para os alunos surdos um pouco da história da Educação voltada para eles e o grande avanço que já ocorreu e ainda as conquistas que podem ser almejadas, nessa mediação é importante o papel do professor como articulador e utilizar estratégias, métodos de ensino que sejam adequados à forma de aprendizagem do aluno onde engloba a cultura surda a literatura visual com as disciplinas a serem ministradas na escola, bem como a utilização de materiais pedagógicos adaptados com referências na cultura surda que contribuirá no processo ensino- aprendizagem do estudante surdo.

\section{REFERÊNCIAS}

KARNOPP, Lodenir Becker. Produções culturais de surdos: análise da literatura surda. Cadernos de Educação. FaE/PPGE/UFPel. Pelotas. v. 36, p.155 - 174.

PERLIN, G. e STROBEL, K. Fundamentos Da Educação De Surdos. UFSC, 2008.

PORTO, Shirley; PEIXOTO, Janaína. Literatura Visual. Revista Letras Libras. Biblioteca UFBP. Disponível em http://biblioteca.virtual ufpb.br/files/literatura_visual_ 1462975268.pdf>. Acesso em 05 Out. 2016.

REIS, V.P.F. A Criança Surda e seu Mundo: O Estado da Arte, As Políticas e as Intevenções Necessárias. Dissertação de mestrado. UFES, 1992.

STROBEL, Karin. As imagens do outro sobre a cultura surda. Florianópolis. Editora UFSC. 2008. Karin. História da Educação de Surdos. Florianópolis. Editora UFSC. 2009. 
RIJO, M. A Inclusão de Alunos Surdos nas Escolas Públicas de Passo Fundo. Trabalho de conclusão Curso de Especialização: Educação Profissional e Tecnológica Inclusiva. Cuiabá: Instituto Federal do Mato Grosso, 2009. 